\title{
PERAN KODIM 0818/MALANG-BATU DALAM PEMBERDAYAAN WILAYAH PERTAHANAN GUNA MENGAMANKAN PILKADA SERENTAK DI KABUPATEN MALANG TAHUN 2020
}

\author{
Dadan Kurnia $^{1}$ Agus Subagyo ${ }^{2}$ \\ Iing Nurdin ${ }^{3}$ Bayu Septiansyah ${ }^{4}$ \\ ${ }^{1,2,3,4}$ Program Studi Ilmu Pemerintahan, Fakultas Ilmu Sosial dan Ilmu Politik, Universitas \\ Jenderal Achmad Yani, Indonesia
}

\begin{abstract}
Abstrak
Tujuan dalam penelitian ini adalah Untuk mengetahui dan mendeskripsikan Peran Kodim 0818/Malang-Batu Dalam Pemberdayaan Wilayah Pertahanan Guna Mengamankan Pilkada Serentak di Kabupaten Malang Tahun 2020. Metode dalam penelitian ini menggunakan penelitian kualitatif, dalam penelitian kualitatif menggunakan metode kualitatif yaitu pengamatan, wawancara dan penelaahan dokumen. Berdasarkan hasil penelitan dapat di simpulkan bahwa Peran Satkowil Kodim 0818/Malang-Batu dalam mengamankan pilkada 2020 di Kabupaten Malang, telah mampu mendukung terciptanya kondisi masyarakat yang aman dan tenteram serta mengawal pembangunan nasional, sehingga mendapat apresiasi dan penghargaan dari seluruh stakeholders yang ada di wilayah teritorial Kodim 0818/Malang-Batu, terutama apresiasi yang sangat tinggi dari masyarakat umum. Hal ini menjadi modal sosial yang sangat berharga bagi satkowil untuk terus meningkatkan kinerja dan profesionalismenya sebagai "tentara rakyat dan tentara pejuang.
\end{abstract}

Kata kunci: Peran, Kodim, Pilkada

\begin{abstract}
The purpose of this research is to find out and describe the role of Kodim 0818/Malang-Batu in Empowerment of Defense Areas to Secure the Simultaneous Regional Elections in Malang Regency in 2020. The method in this study uses qualitative research, in qualitative research using qualitative methods namely observation, interview and review document. Based on the results of the research, it can be concluded that the role of Satkowil Kodim 0818/MalangBatu in securing the 2020 regional elections in Malang Regency, has been able to support the creation of a safe and secure community condition and guard national development, so that it gets appreciation and appreciation from all stakeholders in the region. territorial Kodim 0818/Malang-Batu, especially the very high appreciation from the general public. This has become a very valuable social asset for the satkowil to continue to improve its performance and professionalism as "the people's army and warrior army.
\end{abstract}

Keywords: Role, Kodim, Pilkada 


\section{PENDAHULUAN}

Pemilihan Kepala Daerah (Pilkada), adalah instrumen politik paling sahih dalam Negara demokrasi. Pilkada bahkan dinilai sebagai manifestasi kedaulatan masyarakat dalam rangka melakukan rekrutmen kepemimpinan di daerahnya masing-masing. Gagasan Pilkada sebenarnya merupakan proses lanjut dari keinginan kuat untuk memperbaiki kualitas demokrasi yang berlangsung di dunia, khususnya di Indonesia, sekaligus sebagai upaya lain untuk menghindari adanya praktek demokrasi semu (pseudo democracy) yang dapat memberangus demokrasi itu sendiri. Pilkada juga dimaksudkan untuk memenuhi hak-hak individu agar terdapat peluang yang lebih terbuka dan partisipatif dalam menentukan pemimpin sebagai bagian dari upaya meningkatkan kesejahteraan. Artinya, Pilkada merupakan upaya dalam memberi kesempatan yang lebih luas kepada masyarakat untuk terlibat di dalam berbagai proses politik.

Kontestasi lima tahunan untuk mencari calon pemimpin ideal, kerap masih terantuk kerikil dan batu. Berbagai pelanggaran dalam masa Pemilu maupun Pilkada, masih terus menjadi warna yang lengket. Tak terkecuali di Kabupaten Malang yang bersiap menggelar Pilkada 2020 dan kini sudah mulai terlihat memanas suhunya.

Meningkatnya pragmatisme dalam Pilkada pun ditunjukan dengan rasionalitas ekonomi yang menguat. Salah satu kekhawatiran dalam Pilkada serentak 2020 adalah semakin maraknya politik uang, ujaran kebencian (hate speech), berita hoax, kampanye berdasarkan SARA dan lain-lain. Bagaimana tidak, hampir setiap perhelatan demokrasi elektoral yang melibatkan massa selalu ditemukan praktik politik uang. Pada Pilkada 2020 yang lalu hampir seluruh wilayah Indonesia mengalami polarisasi massa amat kuat. Aktor politik secara langsung/tak langsung menggunakan kampanye jahat, pembohongan (hoax), berita palsu (fake news), dan politisasi identitas. Media sosial dan aplikasi percakapan memfasilitasi dan menjadi pemicu berkembangnya kampanye jahat, hoax, dan politisasi identitas. Pengguna media sosial dan aplikasi percakapan larut dalam emosi sebagai lovers atau haters terhadap politisi yang mengejar/mempertahankan kekuasaan. Facebook, Twitter, Whatsapp, LINE, dan BBM memediasi begitu cepat dan berefek domino merusak nalar dan percakapan banyak warganet. Korupsi politik pun dipraktikan dengan berbagai bentuk. Ada jual/beli tiket pencalonan di pemilu dan pemilu (candidacy buying) yang dijadikan mekanisme pembiayaan kerja elite dan organisasi partai politik. Lalu ada vote buying dan menyuap penyelenggara atau hakim pemilu. Semua merupakan virus demokrasi yang masih dianggap ampuh memenangkan kompetisi pemilu.

Pada prakteknya, dan berdasarkan pengalaman pada pilkada sebelumnya, pelaksanaan 
Pilkada cenderung menimbulkan potensi kerawanan terjadinya gejolak sosial dan tindakan anarkisme yang mengarah pada potensi konflik sosial, komunal dan konflik lebih besar yang dapat mengganggu ketertiban publik secara eskalatif dan menjadi ancaman sosial yang mengarah pada terciptanya instabilitas keamanan di daerah. Hal ini akan sangat berpengaruh terhadap perkembangan dan kelangsungan hidup bermasyarakat di daerah, sehingga menuntut aplikasi peran, fungsi dan tugas Aparat Komando Kewilayahan (Apkowil) TNI AD tingkat Babinsa, Koramil dan Kodim dalam melaksanakan pembinaan teritorial atau pembinaan wilayah khususnya pembinaan upaya mencegah timbulnya potensi kerawanan konflik sosial dari ekses penyelenggaraan Pilkada Serentak.

Agar penyelenggaraan Pilkada berlangsung dengan sukses, tentu harus dibarengi dengan situasi keamanan dan ketertiban masyarakat (Kamtibmas) yang kondusif. Disinilah peran penting Aparat Satuan Komando Kewilayahan (Satkowil) sebagai pengemban fungsi pemerintahan yang bertugas sebagai penjaga kedaulatan NKRI dan pelayan masyarakat, untuk bertanggung jawab dalam mengawal pelaksanaan Pilkada agar berjalan dengan damai dan tertib. Untuk menjawab potensi permasalahan yang muncul di Pikada serentak, maka TNI mempunyai peran yang cukup vital sesuai dengan UU TNI berdasarkan UU No 34 Tahun 2004 pada pasal 7 ayat (2) huruf b angka 10.

TNI AD sebagai salah satu komponen utama pertahanan berdasarkan UU No 34 Tahun 2004 pada pasal 7 ayat (2) huruf b angka 10 disebutkan bahwa Operasi Militer Selain Perang (OMSP) adalah membantu Polri untuk tugas keamanan dan ketertiban masyarakat. Sehingga, peran TNI melalui aparat Satkowil menjadi penting dalam pengamanan pilkada serentak 2020, khususnya di wilayah Kodim 0818/Malang-Batu sebagai bagian dari pemberdayaan wilayah pertahanan, untuk mengawal keberlangsungan pembangunan nasional.

Berdasarkan latar belakang masalah maka dilakukan penelitian tentang Peran Kodim 0818/Malang-Batu Dalam Pemberdayaan Wilayah Pertahanan Guna Mengamankan Pilkada Serentak Di Kabupaten Malang Tahun 2020. Adapun yang menjadi rumusan masalah dalam penelitian ini ialah Bagaimana Peran Kodim 0818/Malang-Batu Dalam Pemberdayaan Wilayah Pertahanan Guna Mengamankan Pilkada Serentak Di Kabupaten Malang Tahun 2020. Adapun tujuan penelitian ini ialah untuk mengetahui dan mendeskripsikan Peran Kodim 0818/Malang-Batu Dalam Pemberdayaan Wilayah Pertahanan Guna Mengamankan Pilkada Serentak Di Kabupaten Malang Tahun 2020. 


\section{METODE PENELITIAN}

Penelitian ini menggunakan pendekatan deskriptif, proses penelitian kualitatif bersifat seni, dan disebut sebagai metode interpretive karena data hasil penelitian berkenaan dengan interprestasi terhadap data yang ditemukan dilapangan (Sugiyono, 2013). Lebih lanjut (Sugiyono, 2013) menjelaskan bahwa metode penelitian kualitatif digunakan pada kondisi objek yang alamiah dimana peneliti sebagai instrumen kunci. Oleh karena itu penelitian ini lebih menekankan pada metode atau pendekatan penelitian deskriptif kualitatif.

Penelitian yang dilakukan ini bertempat di wilayah Kabupaten Malang-Batu. Waktu penelitian adalah rentang waktu yang digunakan selama proses penyusunan proposal hingga penelitian berlangsung, mulai dari tahap persiapan sampai pada tahap penyusunan laporan sesuai dengan sasaran penelitian.

Pengumpulan data dalam penelitian ini peneliti akan menggunakan prosedur pengumpulan data antara lain : Observasi, dengan cara ini peneliti dapat meyakini, dapat melihat dan dapat mengamati sendiri yang kemudian dilanjutkan dengan pencatatan perilaku serta kejadian sebagai mana adanya. Wawancara, melakukan wawancara langsung kepada semua pihak yang berkompoten dalam penelitian ini, agar informasi yang didapatkan tidak meragukan dan dapat dipertanggung jawabkan. Dokumentasi, dokumentasi yakni pengumpulan data dari sumber-sumber non visual yakni berupa dokumen-dokumen atau arsip-arsip dan rekaman yang ada relevansinya dengan kebutuhan data yang dibutuhkan peneliti.

\section{HASIL DAN PEMBAHASAN}

Sejumlah peristiwa mengejutkan yang terjadi jelang pencalonan kepala daerah, misalnya, membuktikan itu. Belum lagi energi yang harus dikeluarkan selama proses pilkada serentak yang amat melelahkan. Tercatat, gesekan-gesekan antar pendukung pasangan calon dan partai politik sudah mulai terasa. Selain itu, peningkatan penyebaran informasi hoax yang bisa memicu kericuhan di masyarakat. Hoax disebar karena ada aktor ingin memanfaatkan situasi yang berkembang. Dan polarisasi yang terbentuk selama ini menyebabkan identitas primordial, kesukuan, agama, dan kesenjangan sosial dapat dimanfaatkan menimbulkan anarkisme massa. Oleh karena itu, aparat keamanan yaitu khususnya TNI AD dalam hal ini aparat Satkowil dituntut supaya bisa mengelola perbedaan yang ada di tengah masyarakat dengan baik, sehingga tidak menjadi sumber konflik.

Keterlibatan dan Peran Kodim 0818/Malang-Batu dalam pemberdayaan wilayah pertahanan guna mengamankan Pilkada di Kabupaten Malang Tahun 2020 dalam rangka mengawal keberlangsungan pembangunan nasional adalah sebagai bentuk keterpanggilan dan 
kepedulian untuk ikut serta menjaga kedaulatan dan keutuhan Negara Kesatuan Republik Indonesia. Karena sesuai Undang-Undang yang berlaku, bahwa penempatan peran TNI dalam penanganan konflik sosial dan pengamanan pemilu adalah pada posisi membantu instansi lain sesuai permintaan. Namun kenyataannya kondisi di lapangan yang terjadi justru sebaliknya, seolah-olah aparat TNI sebagai pihak yang paling bertanggung jawab sehingga dengan keterbatasan yang ada dituntut untuk terjun ke lapangan mewujudkan rasa aman di masyarakat.

Dalam upaya dalam menciptakan kondisi sosial, politik dan keamanan yang kondusif selama proses pilkada 2020 di wilayah Kodim 0818/Malang-Batu telah dilaksanakan tugas perbantuan sesuai dengan amanat UU No.34 tahun 2004 dan tugas pokok OMSP Selain itu, peran Kodim 0818/Malang-Batu dalam dalam menciptakan kondisi sosial, politik dan keamanan yang kondusif pada Pilkada serentak 2020 di Kabupaten Malang didasarkan secara lebih khusus kepada Petunjuk Teritorial Kodim 0818/Malang-Batu dan Program Binter 2020 Kodim 0818/Kabupaten Malang-Batu.

Petunjuk Teritorial Kodim 0818/Malang-Batu dan Program Binter 2020 Kodim 0818/Malang-Batu ini disusun untuk memberikan gambaran kepada seluruh anggota Petunjuk Teritorial Kodim 0818/Malang-Batu dan Program Binter 2020 Kodim 0818/Malang-Batu dalam menciptakan kondisi sosial, politik dan keamanan yang kondusif pada pilkada serentak 2020. Sementara tujuannya adalah sebagai pedoman dalam mengambil langkah-langkah untuk menciptakan kondisi sosial, politik dan keamanan yang kondusif pasca pilkada 2020 secara cepat dan tepat, agar konflik dan kerugian yang timbul dapat diminimalisasikan. Berdasarkan hasil wawancara dengan Dandim 0818/Malang Batu, bahwa:

"Untuk mengamankan Pilkada di Kabupaten Malang Tahun 2020 dalam rangka mengawal keberlangsungan pembangunan nasional, Kodim 0818/Kabupaten Malang-Batu memaparkan sejumlah langkah antisipasi yang telah disiapkan. Pemetaan potensi konflik juga sudah dilakukan. Antara lain melaksanakan pengumpulan data dan pemetaan adanya potensi konflik maupun indikasi pengarahan massa di masing-masing wilayah. Melalui pembinaan teritorial, saya telah memerintahkan tiap satuan kewilayahan untuk membangun kedewasaan politik masyarakat. TNI menerapkan deteksi dini, cegah dini, serta temu cepat dan lapor cepat. Lalu, patroli TNI bersama Polri. Pasukan cadangan dan alutsista juga disiagakan, termasuk untuk mewaspadai adanya serangan terorisme”.

Adpun arahan dari Panglima TNI yang selanjutnya diimplementasikan oleh Satkowil Kodim 0818/Malang-Batu melalui Petunjuk Teritorial Kodim 0818/Malang-Batu berisi upaya-upaya dalam menciptakan kondisi sosial, politik dan keamanan yang kondusif pada pilkada serentak 2020 yang dilakukan oleh Kodim 0818/Malang-Batu. Berdasarkan dokumen 
Laporan Satuan Tahun 2020 Kodim 0818/Malang-Batu upaya-upaya itu adalah sebagai berikut:

1. Bidang Hankam.

a. Senantiasa melakukan pengendalian dan pengawasan terhadap seluruh wilayah di jajaran Kodim 0818/Malang-Batu untuk selalu siap sedia menghadapi permasalahan yang mungkin timbul, serta menghimpun mitra kerja Babinsa untuk melakukan temu cepat dan lapor cepat.

b. Kodim 0818/Malang-Batu mengkomunikasikan dan mengkoordinasikan permasalahan yang timbul pada Rakor Forkopimda.

2. Bidang Teritorial

a. Melaksanakan kegiatan pembinaan kesiapan dan kemampuan Aparat Kowil;

b. Menyelenggarakan evaluasi dan kajian organisasi Satkowil;

c. Melaksanakan pengawasan dan evaluasi kegiatan pendayagunaan Koramil Model;

d. Melaksanakan Kajian dan evaluasi organisasi Satkowil.

3. Bidang Ketahanan Wilayah.

a. Melaksanakan, menghimpun, penyusunan dan inventarisasi data Perlawanan Wilayah yang terdiri dari RT/RW, SDAB, SDM dan Komsos;

b. Melaksanakan sosialisasi Petunjuk Penyelenggaraan Saka Wira Kartika;

c. Melaksanakan sosialisasi kegiatan Ketahanan Pangan;

d. Melaksanakan pembinaan Tata Ruang Wilayah Pertahanan Darat;

e. Melaksanakan sosialisasi pedoman dan inventarisasi data RT/RW, SDM dan Konsos untuk kepentingan Pertahanan Negara;

f. Melaksanakan pembinaan Peta Jarak Jaring Teritorial;

g. Melaksanakan sosialisasi menyikapi bangkitnya kembali Komunis dan Faham Radikal;

h. Melaksanakan pengawasan dan evaluasi kegiatan bidang Wanwil;dan

i. Menyelenggarakan kegiatan pembinaan ke Pramukaan.

4. Bidang Komunikasi Sosial.

a. Melaksanakan Peningkatan Kemampuan Komsos bagi prajurit Kodim 0818/Malang-Batu agar meningkatnya pengetahuan dan keterampilan prajurit dalam bidang komunikasi sosial dengan komponen bangsa lainnya;

b. Menyelenggarakan kegiatan Komsos dengan Aparat Pemerintah agar terbangun pemahaman yang positif tentang Binter TNI AD dan terjalin kerjasama yang erat dalam pemberdayaan wilayah pertahanan di darat;

c. Menyelenggarakan kegiatan Komsos dengan Komponen Masyarakat agar terbangun hubungan emosional yang positif antar prajurit dengan masyarakat, sehingga prajurit Kodim 0818/Kabupaten Malang-Batu mencintai dan dicintai rakyat serta terbangun kesadaran bela negara masyarakat;

d. Menyelenggarakan kegiatan Komsos dengan KB TNI agar tetap terjalin hubungan emosional yang erat antara KB TNI dengan prajurit aktif, untuk memberikan efek tangkal bidang pertahanan negara;

e. Melaksanakan kegiatan Komsos Kreatif agar tetap terjalin hubungan emosional yang erat antara TNI dengan prajurit aktif, untuk memberikan efek tangkal bidang pertahanan negara;

f. Mengikuti kegiatan Sosialisasi 4 (empat) pilar Kebangsaan dari Komando Atas.

5. Bidang Politik. 
a. Penyelenggaraan pemerintahan di wilayah Kodim 0818/Malang-Batu dengan berpedoman kepada UU Nomor 32 tahun 2004 tentang Pokok-Pokok Pemerintahan Wilayah berjalan dengan lancar, baik di tingkat Kabupaten/Kota, tingkat Kecamatan maupun tingkat Desa/Kelurahan.

b. Hubungan antar umat beragama di wilayah jajaran Kodim 0818/Kabupaten Malang-Batu sangat harmonis dan kondusif terutama sejak adanya Forum Komunikasi Umat Beragama (FKUB) dan sampai saat ini belum terlihat adanya indikasi sentimen antar umat beragama.

c. Bantuan TNI kepada Polri.

d. Mendinamisir Pemda agar lebih mengintensifkan penyebarluasan Bela Negara kepada seluruh lapisan masyarakat, terutama melalui ceramah - ceramah dan penyuluhan dengan menitik beratkan masalah kesadaran dan ketahanan bidang Hanneg.

e. Lebih mengintensifkan / menggalakan sistem pam swakarsa dalam wujud siskamling sampai kedesa - desa.

f. Secara berkala melakukan ceramah kesekolah - sekolah, instansi dan masyarakat umum dengan materi UUD 1945 pasal 30 dan UU No. 3/2002.

g. Menggunakan pengaruh dari pemuka-pemuka agama, kaum cerdik pandai, orang-orang yang ditugaskan untuk mengadakan dakwah pada hari-hari besar Islam dan kegiatan lainnya seperti melalui perwiritan, dimana mereka untuk menarik simpatisan masyarakat.

h. Berusaha menarik simpatisan masyarakat dan menanamkan pengaruh melalui penerangan pembangunan yang terus di giatkan dari kepentingan dan kemajuan masyarakat itu sendiri.

6. Bidang Kondisi Sosial.

a. Meningkatnya penghayatan dan pengamalan Pancasila, UU'45 di wilayah Kodim 0818/Malang-Batu.

b. Terjalinnya kerjasama yang harmonis antara Parpol, masyarakat dan pemda.

c. Mempelopori usaha - usaha untuk meningkatkan perekonomian rakyat dengan cara memberikan penyuluhan - penyuluhan bekerjasama dengan instansi terkait dalam bidang koperasi, pertanian, perkebunan dan perikanan serta pariwisata.

d. Menentang usaha - usaha yang ingin memecah belah antara suku, kelompok maupun agama atau golongan.

e. Mempelopori usaha yang sifatnya melestarikan kebudayaan nenek moyang sepanjang tidak bertentangan dengan norma agama dan kepercayaan.

7. Bidang Operasi.

a. Satuan jajaran Kodim 0818/Malang-Batu telah melaksanakan bantuan perkuatan kepada Polri atas permintaan, dengan Melaksanakan tugas bantuan TNI kepada Polri/Pemda dalam rangka Pam pilkada serentak 2020.

b. Satuan jajaran Kodim 0818/Malang-Batu telah melaksanakan bantuan perkuatan kepada Polri atas permintaan, dengan Melaksanakan tugas bantuan TNI kepada Polri/Pemda dalam rangka kunjungan kerja pejabat publik dan pejabat TNI di Kodim 0818/Malang-Batu.

c. Satuan jajaran Kodim 0818/Malang-Batu telah melaksanakan bantuan perkuatan kepada Polri atas permintaan, dengan melaksanakan tugas bantuan TNI kepada Polri/Pemda dalam rangka pengamanan pilkada 2020.

Peran Satkowil dalam upaya untuk mengamankan Pilkada di Kabupaten Malang 
Tahun 2020 dalam rangka mengawal keberlangsungan pembangunan nasional di wilayah Kodim 0818/Malang-Batu didasarkan pada tugas OMSP. Menurut Dandim 0818/MalangBatu, Letkol Ferry Muzawwad,S.I.P, bahwa:

"Tugas TNI AD selama Pilkada 2020 di Kabupaten Malang adalah tugas perbantuan. Kehadiran TNI AD membantu Polri sesuai ketentuan yang ada. Tugas TNI AD dalam mengamankan Pilkada di Kabupaten Malang Tahun 2020 antara lain, pertama, melaksanakan pemetaan daerah rawan konflik, kedua mengoptimalkan peran Forkompimda, Ketiga memaksimalkan perbantuan pada Polri. Sesuai amanat Undang-Undang, kami juga mengamankan wilayah teritorial untuk mengantisipasi dan mendeteksi kemungkinan yang muncul di lapangan yang mungkin akan mengganggu dan menyebabkan kegagalan pilkada 2020 di Kabupaten Malang. Dasar Hukum Perbantuan TNI berdasarkan Undang- undang Nomor 34 Tahun 2004 tentag TNI pada pasal 7 ayat 2 huruf b angka 10 yang berbunyi Membantu kepolisian Negara Republik Indonesia dalam rangka tugas keamanan dan ketertiban masyarakat yang diatur dalam undang-undang".

Lebih lanjut Dandim 0818/Kabupaten Malang-Batu menjelaskan:

"adapun bentuk strategi TNI dalam pengamanan Pemilu bahwa TNI tidak bertindak sendiri. Jika ada permintaan secara lisan maupun tertulis dari Kepolisian, maka TNI siap bergerak dalam waktu 1x24 berdasarkan potensi yang ada seperti kemungkinan dan potensi yang bisa terjadi bentrok antar pendukung. Saya minta kepada seluruh aparat pemerintah seperti Camat, Lurah dan Kepala Desa agar dapat memberikan sosialisasi kepada masyarakatnya agar menghindari pelanggaran yang tak sesuai aturan, mengajak masyarakat agar tidak golput serta dapat merangkul masyarakat. Aparat Kodim 0818/Malang-Batu di-BKO-kan pergerakannya atas permintaan kepolisian. Tujuannya menjalin sinergitas dengan Polres Kabupaten Malang dengan apel gelar pasukan, patroli bersama, serta deteksi dini untuk pencegahan segala ancaman yang mungkin terjadi di wilayah Kodim 0818/Malang-Batu dalam mengamankan Pilkada 2020 di wilayah Malang”.

Selanjutnya wawancara dengan Pemerintah Kabupaten Malang, yang diwakili oleh

Kepala Kesbangpol, menyatakan bahwa:

"Dalam rangka meminimalisasi dampak hoax dan indikasi perpecahan serta konflik horizontal di masyarakat, Pemda Kabupaten Malang dan aparat Satkowil Kodim 0818/Malang-Batu bekerjasama dalam bentuk pemantauan dan monitoring perkembangan situasi melalui pemberdayaan Forum Kewaspadaan Dini Masyarakat (FKDM), dan koordinasi dengan aparat intelejen instansi terkait di Malang; Pemberdayaan FKUB, para tokoh masyarakat, tokoh agama untuk bersama-sama menjaga kerukunan dan toleransi antara umat beragama; melakukan komunikasi dan koordinasi yang intens dengan tokoh masyarakat, agama, pengurus partai politik, tim kampanye, dan penyelenggara pemilu; bekerjasama untuk memberdayakan seluruh potensi dan stakeholders yang ada di Kabupaten Malang serta berkoordinasi dengan aparat keamanan TNI dan Polri; bersama TNI-Polri, penyelenggara pemilu KPU dan Bawaslu Kabupaten Malangmemberikan himbauan kepada masyarakat dan para pendukung pasangan calon maupun partai politik untuk tetap menjaga persatuan dan kesatuan melalui kegiatan tatap muka, pemasangan baligo, spanduk yang berisi himbauan, pengajian dan pertemuan-pertemuan lainnnya". 
Hasil wawancara dengan Aparat Pemerintah Pemda Kabupaten Malang, seperti yang diwakili oleh Camat Kepanjen, menyatakan bahwa:

\begin{abstract}
"upaya-upaya yang dilakukan oleh satkowil Kodim 0818/Malang-Batu dalam menciptakan masyarakat yang kondusif adalah dengan melakukan koordinasi dengan semua stakeholders yang ada di Kabupaten Malang. Dalam setiap rapat Forkopimda, aparat satkowil biasanya memberikan masukan dan saran, sosialisasi dan pemberdayaan masyarakat, mengajak masyarakat untuk bergotong royong dan bersama-sama mensukseskan pemilu, sosialisasi tentang bahaya hoax, mengajak masyarakat untuk menjaga ketertiban dan keamanan selama proses pemilu dan sesudahnya."
\end{abstract}

Sedangkan hasil wawancara Menurut penjelasan Wakapolres Malang, bahwa"

"Kodim selaku satkowil harus dapat mengetahui dan menguasai situasi Astagatra yang berada di wilayah Kodim 0818/Malang-Batu khususnya di Kabupaten Malang, dengan melakukan upaya dan langkah-langkah: a) menjalin koordinasi dengan berbagai unsur Forkopimda; b) menjalin silaturahmi dan komunikasi dengan seluruh elemen masyarakat; c) c. melakukan koordinasi dengan penyelenggara pemilu yaitu KPU dan Bawaslu daerah serta dengan pengurus parpol; d) melakukan pemetaan kerawanan kamtibmas, serta potensi gangguan kamtbmas; e) menentukan langkahlangkah dan kebijakan dalam upaya pencegahan gangguan kamtibmas; f) meningkatkan pola kegiatan keamanan dalam upaya memelihara situasi masyarakat dan kamtibmas yang kondusif; dan g) menjabarkan dan menindaklanjuti perintah pimpinan untuk tetap memberikan pelayanan dan perlindungan terhadap masyarakat".

Lebih jauh wawancara dengan Wakapolres Malang menambahkan bahwa:

"upaya bersama antara TNI dengan Polri dalam menciptakan kondisi masyarakat yang kondusif dilakukan dengan cara: a) membentuk kegiatan dan program kerja yang tergabung dalam 3 pilar yang melibatkan Pemerintahan Desa, Babinkamtibmas dan Babinsa; b) melaksanakan kegiatan bersama dengan pola kegiatan patroli bersama gabungan TNI dan Polri; dan secara bersama-sama dengan aparat desa maupun aparat tingkat kecamatan melakukan kegiatan gotong royong, binluh, pertemuan tatap muka dengan warga masyarakat, deklarasi kampanye damai dan penempatan aparat di setiap TPS untuk monitoring pelaksanaan pemungutan dan penghitungan suara. Hasilnya sangat dirasakan oleh masyarakat, karena masyarakat merasakan kehadiran aparat dan memberikan jaminan rasa aman dan nyaman selama pelaksanaan dan pasca pemilu”.

Secara keseluruhan proses penyelenggaraan pilkada 2020 di Kabupaten Malang serta kondisi sosial, politik dan keamanan di wilayah Kodim 0818/Malang-Batu sejauh ini berjalan dengan relatif lancar, aman, terkendali dan kondusif. Tolak ukur atau indikator dari kondusivitas tersebut dapat dilihat dari tidak adanya demonstrasi, kerusuhan apalagi konflik yang terjadi selama penyelenggaraan pilkada 2020. Pelaksanaan pilkada 2020 diharapkan berlangsung relatif langsung, umum, bebas, rahasia, jujur, adil dan aman terkendali. Memang sudah mulai ada riak-riak atau suasana panas atau persaingan antara kelompok masyarakat 
pendukung terutama pendukung pasangan calon Bupati dan Wakil Bupati, namun persaingan atau suasana panas tersebut tidak meledak menjadi konflik horizontal antara pendukung dan masyarakat.

\section{Hambatan yang dihadapi oleh Kodim 0818/Malang-Batu dalam pemberdayaan wilayah pertahanan guna mengamankan Pilkada di Kabupaten Malang Tahun 2020}

Masyarakat di wilayah Kodim 0818/Kabupaten Malang-Batu, khususnya Kabupaten Malang mempunyai catatan indeks kerawanan yang sedang dan mengarah tinggi. Hal ini disebabkan karena potensi-potensi money politik, jumlah pemilih yang cukup banyak, sumber daya manusia penyelenggara yang kurang kompeten, serta perbedaan agama, kepercayaan dan budaya yang cukup besar menjadi masalah-masalah yang krusial. Menjelang Pilkada 2020, terkendala masalah keamanan, DPT yang bermasalah, masalah rekam E-KTP. Adanya ketidakpuasan dari peserta pemilu legislatif yang melakukan gugatan ke Mahkamah Konstitusi juga dapat berpengaruh kepada kondusivitas di masyarakat apabila dibiarkan tanpa penyelesaian.

Secara umum, Hambatan-hambatan yang masih dihadapi oleh Kodim 0818/Kabupaten Malang, dalam mengamankan pilkada 2020 guna mengawal pembangunan nasional, antara lain:

1. Permasalahan pada pelaksanaan pilkada 2020, justru berasal dari internal aparat Satkowil sendiri dalam membantu dalam kegiatan pengamanan bersama dengan pihak polisi. Kendala yang dihadapi adalah kekurangan jumlah aparat satkowil dan Babinsa untuk pengamanan pilkada 2020.

2. Beberapa orang personil aparat Satkowil yang dirasa kurang dalam hal pengetahuan dan pemahaman, khususnya aturan-aturan yang terkait dengan pemilu, komsos dan binter. Berdasarkan data Laporan Satuan Kodim 0818/Malang-Batu, Aparat Satuan Jajaran Kodim 0818/Malang-Batu masih kekurangan Babinsa sehingga jabatan Babinsa masih dijabat oleh Tamtama, Masih ada personel Perwira dan Bintara Satuan Jajaran Kodim 0818/Malang-Batu yang belum kursus sesuai kualifikasi jabatan.

3. Bidang Intelejen, Keterbatasan Kemampuan personel Intelijen Kodim 0818/MalangBatu yang dihadapkan dengan luas wilayah sangat mempengaruhi kegiatan usaha temu cepat dan lapor cepat. Personel intel secara kualitas belum memiliki naluri Intelijen yang peka terhadap setiap permasalahan dan perkembangan yang timbul maupun yang bakal timbul dan Jumlah personel unit Intel yang terbatas hanya 10 
orang sehingga menimbulkan kesulitan mengcover wilayah Kodim yang terdiri dari 2 pemerintahan 1 Kabupaten dan 1 Kota.

4. Payung hukum perundang-undangan. Walaupun OMSP secara jelas telah diatur dalam UU No. 34 Tahun 2014, Doktrin TNI Tri Dharma Eka Karma (Tridek) yang ditetapkan berdasarkan Keputusan Panglima TNI Nomor Kep/2/1/2007, Peraturan Pemerintah Nomor 2 tahun 2015 tentang Peraturan Pelaksanaan Undang-Undang Nomor 7 Tahun 2012 tentang Penanganan Konflik Sosial, namun peran Aparat Satkowil atau TNI masih merupakan tugas perbantuan. Konsekuensi dari tugas OMSP dalam bentuk tugas perbantuan ini adalah bahwa Aparat Satkowil TNI hanya merupakan pembantu yang ada dibawah kendali institusi lain. Selain itu, aparat satkowil TNI "hanya sekedar" menunggu perintah dari institusi lain dan bersifat menunggu. Hal ini membuat posisi aparat satkowil seringkali dianggap lamban oleh masyarakat karena dianggap tidak punya insiatif dan cenderung lamban.

\section{KESIMPULAN}

Secara umum Peran Satkowil Kodim 0818/Malang-Batu dalam mengamankan pilkada 2020 guna mengawal pembangunan nasional di wilayah Kodim 0818/Malang-Batu sudah berjalan dengan baik. Hal ini bisa terlihat dari data yang didapatkan baik data primer maupun data sekunder yang memperlihatkan bahwa upaya-upaya yang dilakukan oleh aparat Satkowil sudah mampu mewujudkan suatu kondisi penyelenggaraan pilkada 2020 di Kabupaten Malang berlangsung aman dan terkendali. Indikator keberhasilan itu bisa dilihat dari relatif tidak adanya konflik, kerusuhan dan demonstrasi terkait dengan kondisi penyelenggaraan pilkada 2020 di Kabupaten Malang. Dengan menggunakan teori peran maka dapat dibuktikan bahwa pertama, tugas-tugas OMSP yang diemban secara institusional oleh Satkowil Kodim 0818/Malang-Batu sudah dapat dijalankan dengan berhasil; kedua, tindakan-tindakan atau tugas-tugas yang dijalankan oleh aparat Satkowil Kodim 0818/Malang-Batu sudah sesuai dengan harapan atau ekspektasi masyarakat terhadap TNI sebagai institusi yang dianggap mampu dan harus menjaga integrasi bangsa dan keutuhan NKRI, serta mampu memberikan jaminan rasa aman kepada masyarakat serta mengawal pembangunan nasional secara menyeluruh.

Adapun rekomendasi sebagai berikut :

1. Aspek personil; a) perlunya pemenuhan jumlah personil sesuai dengan standar dan prosedur yang berlaku; b) perlunya peningkatan kompetensi, kemampuan dan 
wawasan personil seiring dengan perkembangan jaman, perkembangan teknologi, perkembangan lingkungan strategis geopilitik dan konstelasi dunia internasional.

2. Aspek Anggaran dan sarana prasarana; perlunya ketersediaan dana yang memadai dalam setiap operasi termasuk dalam operasi OMSP yang sifatnya perbantuan.

3. Aspek yuridis; perlunya peraturan yang terperinci dan jelas terkait posisi dan tindakan-tindakan yang harus dilakukan oleh aparat Satkowil dalam tugas-tugas OMSP/perbantuan kepada institusi yang lain.

4. Penyempurnaan prosedur-prosedur perbantuan dari Satkowil kepada institusi lain sehingga dapat menghilangkan kesan "dibawah kendali atau dibawah perintah". Dalam hal ini diperlukan komunikasi dan koordinasi lebih intensif diantara semua institusi/instansi yang lain di daerah.

5. Perlunya menjadikan masyarakat sebagai mitra dalam setiap kegiatan Satkowil khususnya dalam upaya mencegah disintegrasi dan upaya untuk menjaga kedaulatan NKRI.

\section{DAFTAR PUSTAKA}

Anak Agung Banyu Perwita, Pemberdayaan Wilayah Pertahanan Melalui Pembinaan Teritorial Dalam Rangka Pertahanan Negara.(makalah 12) disampaikan dalam Seminar.

BAWASLU RI, 2019, Indeks Kerawanan Pemilu (IKP) 2019, Jakarta, Bawaslu RI

BPS Kabupaten Malang, 2019, Statistik Kabupaten Malang 2019

Connie Rahakundini Bakrie, Pertahanan Negara dan Postur TNI Ideal, (Jakarta : Yayasan Obor Indonesia, 2007).

Effendy, Onong Unchjana. 2007. Strategi Komunikasi, Sebuah Pengantar Ringkas. Bandung : PT. Remaja Rosdakarya.

Georg Sorensen (Terj.). 2003. Demokrasi dan Demokratisasi: (Proses dan Prospek dalam Sebuah Dunia yang sedang Berubah). Jogjakarta. Pustaka Pelajar.

Muhammad Asfar, 2006, Pemilu dan Perilaku Memilih 1955-2004, Pusat Study Demokrasi dan HAM (PusDeHAM), Surabaya

Ramlan Surbakti, 2008, Sistem pemilu dan tatanan politik demokrasi, dalam ramlan surbakti, dkk (Ed.), Perekayasaan Sistem Pemilu untuk Pembangunan tata politik demokratis, Kemitraan Jakarta, hlm 27 , dalam Luki Sandra Amalia, Syamsuddin Haris, Sri nur yanti, Lili Romli, Devi Darmawan, 2016, Evealuasi Pemilu Legislatif 2014 : Analisi Proses dan Hasil, Pustaka Pelajar, Yogyakarta, 
Septi Nur Wijayanti - Iwan Satriawan , 2009, Hukum Tata Negara, Fakultas Hukum Universitas Muhammadiyah Yogyakarta, Yogyakarta

Stoner, James A.F. 2003. Perencanaan dan Pengambilan Keputusan dalam Manajemen. Jakarta : Rineka Cipta.

Sugiyono. 2012. Memahami Penelitian Kualitatif. Bandung : Alfabeta.

Suradinata, Ernaya. 1996. Organisasi Manajemen Pemerintahan Dalam Era Globalisasi. Jakarta : Gramedia Pustaka Utama.

Syamsyudin Haris, dkk, 1997, Pemilihan Umum di Indonesia : Telaah atas Struktur, Proses, dan Fungsi, PPW-LIPI, Jakarta

\section{Dokumen dan Jurnal :}

Undang-Undang Nomor 3 Tahun 2003 tentang Pertahanan Negara.

Undang-Undang Nomor 4 Tahun 2004 tentang Tentara Nasional Indonesia.

Undang-Undang Nomor 7 Tahun 2017 tentang Pemilu.

Undang - Undang Nomor 7 Tahun 2012 tentang Penanganan Konflik Sosial.

Undang - Undang Nomor 23 tahun 2014 tentang Pemerintahan Daerah.

Peraturan Pemerintah Nomor 2 tahun 2015 tentang Peraturan Pelaksanaan Undang-Undang Nomor 7 Tahun 2012 tentang Penanganan Konflik Sosial.

Permenhan RI No. 40 Tahun 2011, tentang Kebijakan Pemberdayaan Wilayah Pertahanan.

Peraturan Komisi Pemilihan Umum Nomor 6 Tahun 2008 tentang Susunan Organisasi dan Tata Kerja Sekretariat Jenderal Komisi Pemilihan Umum, Sekretariat Komisi Pemilihan Umum Provinsi, Sekretariat Komisi Pemilihan Umum Kabupaten/Kota.

Peraturan Badan Pengawas Pemilihan Umum Nomor 2 Tahun 2013 tentang Organisasi dan Tata Kerja Sekretariat Jenderal Badan Pengawas Pemilhan Umum Provinsi, Sekretariat Badan Pengawas Pemilihan Umum Provinsi, Sekretariat Panitia Pengawas Pemilihan Umum Kabupaten/Kota, dan Sekretariat Panitia Pengawas Pemilihan Umum Kecamatan.

Peraturan Sekretaris Jenderal Badan Pengawas Pemilihan Umum Republik Indonesia Nomor 1 Tahun 2017 tentang Tata Cara Pengangkatan, Pemberhentian, dan Pemindahan Kepala Sekretariat dan Pegawai Sekretariat Badan Pengawas Pemilhan Umum Provinsi, Panitia Pengawas Pemilhan Umum Kabupaten/Kota dan Panitia Pengawas Pemilihan Umum Kecamatan.

Keputusan Panglima TNI Nomor Kep/2/1/2007 tentang Doktrin TNI Tri Dharma Eka Karma (Tridek). 